\title{
PHYSICS LEARNING BLOG DEVELOPMENT BASED ON FLIPPED CLASSROOM APPROACH FOR GRADE X MIPA SENIOR HIGH SCHOOL
}

\author{
Willyam Santos Alfrado ${ }^{* 1}$, M. Rahmad ${ }^{2)}$, Muhammad Syafi' ${ }^{3)}$, Nurliana ${ }^{4)}$ \\ ${ }^{1,2,3)}$ Physics Education, University of Riau \\ 4) Senior High School (SMA) 4 Pekanbaru \\ e-mail: willyam29021996@gmail.com \\ m.rahmad@unri.ac.id \\ forsyafii@gmail.com \\ nurliana201506@gmail.com
}

\begin{abstract}
This study aims to develope physics learning blog based on flipped classroom approach for grade X MIPA Senior High School. The developed product was learning blog which can be utilized as learning media for teacher and student at flipped classroom learning. Research method used was R\&D with the ADDIE design approach. Research phase includes analysis, design, development, and evaluation. Data collection instrument include a sheet of students interest in learning using of internet that filled by students and learning blog validity sheet that filled by validator. Data was analyzed using percentage methods and descriptive techniques. Learning blog which has been developed then validated by 3 physics education lecturers as experts and 3 physics teachers as users. Learning blog contain of LKPD, learning videos, online quizzes, and chat. As for the assessment includes content aspect, linguistic aspects, and display aspect. While the avarage score of learning blog validity was 3,17 from experts with high category, while those of users was 3,17 with very high category. Therefore physics learning blog based on flipped classroom approach was valid and feasible to use.
\end{abstract}

Keywords: blog, flipped classroom, work and energy.

\section{PENGEMBANGAN BLOG PEMBELAJARAN FISIKA BERBASIS PENDEKATAN FLIPPED CLASSROOM UNTUK SISWA KELAS X MIPA SEKOLAH MENENGAH ATAS}

\author{
Willyam Santos Alfrado ${ }^{1)}$, M. Rahmad ${ }^{2)}$, Muhammad Syafi'i ${ }^{3)}$, Nurliana ${ }^{4)}$ \\ ${ }^{1,2,3)}$ Pendidikan Fisika, Universitas Riau \\ 4) SMA Negeri 4 Pekanbaru
}

\begin{abstract}
Abstrak
Penelitian ini bertujuan mengembangkan blog pembelajaran fisika berbasis pendekatan flipped classroom untuk siswa kelas X MIPA Sekolah Menengah Atas yang valid. Produk yang dikembangkan berupa blog pembelajaran dan dapat dimanfaatkan oleh guru dan peserta didik sebagai media belajar pada pendekatan flipped classroom. Metode penelitian yang digunakan adalah R\&D dengan pendekatan perancangan ADDIE. Tahap penelitian meliputi analisis, desain, pengembangan, dan evaluasi. Instrumen pengumpulan data meliputi lembar ketertarikan peserta didik terhadap pembelajaran menggunakan internet yang diisi oleh
\end{abstract}


peserta didik dan lembar validitas blog yang diisi oleh validator. Teknik analisis data menggunakan metode persentasi dan teknik analisis deskriptif. Blog yang sudah dikembangkan kemudian divalidasi oleh tiga dosen pendidikan fisika sebagai pakar dan tiga guru bidang studi fisika sebagai pengguna. Konten blog pembelajaran meliputi LKPD, video pembelajaran, kuis online dan obrolan. Penilaian meliputi 3 aspek, yaitu aspek isi, aspek tampilan, dan aspek kebahasaan. Blog pembelajaran yang sudah divalidasi mendapat skor rata-rata 3,17 dari pakar dengan kategori tinggi, sedangkan dari pengguna adalah 3,73 dengan kategori sangat tinggi. Dengan demikian blog pembelajaran fisika berbasis pendekatan flipped classroom dinyatakan valid dan layak digunakan.

Kata kunci: blog, flipped classroom, usaha dan energi.

\section{Pendahuluan}

Belajar adalah usaha sadar dan terencana yang dilakukan individu dalam pemerolehan pengetahuan dan keterampilan secara terus menerus sehingga terjadi perubahan perilaku dalam ranah kognitif, afektif, dan psikomotorik berdasarkan pengalaman berinteraksi dengan lingkungannya (Darmansyah, 2010). Pengertian ini sejalan dengan teori kognitivisme yang menjelaskan bahwa pada diri individu terjadi proses berpikir dan proses genetika didasarkan atas mekanisme biologis yaitu perkembangan syaraf yang membangun kemampuan kognitif melalui tindakan yang termotivasi dengan sendirinya terhadap lingkungan (Bambang Warsita, 2008). Teori kognitivisme menuntut adanya prinsip pembelajaran yang aktif, interaksi sosial, dan mengeksplorasi kognitif nya lebih dalam.

Fisika merupakan ilmu yang mempelajari gejala alam dari sudut pandang materi dan energi. Dalam pembelajaran fisika, peserta didik dituntut memahami konsep dan mampu mengaplikasikan konsep tersebut dalam kehidupan sehari-hari. Pada kenyataannya banyak peserta didik yang kesulitan dalam memahami konsep tersebut dan tidak melihat aplikasi konsep tersebut dalam keseharian mereka. Hal ini dapat diatasi dengan menghadirkan media pembelajaran dalam proses belajar mengajar. Media pembelajaran merupakan segala sesuatu yang dapat digunakan dalam proses belajar mengajar untuk menyampaikan pesan dan informasi sehingga mencapai tujuan belajar yang menyangkut aspek kognitif, afektif, dan psikomotorik (Arsyad, 2013). Arief Sadiman (2012) menjelaskan fungsi media pembelajaran adalah untuk membangkitkan minat, motivasi, rangsangan kegiatan belajar, menjelaskan lebih konkret, meningkatkan pemahaman, menyajikan data, dan memadat kan informasi.

Seiring dengan perkembangan zaman, proses pembelajaran berbasis informasi dan telekomunikasi (IT) sudah tidak terelakkan. Konsep pembelajaran ini disebut sebagai $e$ learning. E-learning merupakan strategi pembelajaran yang tidak menggunakan media cetak melainkan menggunakan teknologi informasi dan komunikasi dalam pengiriman informasi belajar maupun tugas belajar (Summit Goyal, 2012). Manfaat e-learning diantaranya adalah interkasi yang tidak terbatas antara guru dan peserta didik, pembelajaran dapat dilakukan kapanpun dan di manapun, dan menjadi pembelajaran kekinian yang menarik minat peserta didik (Hilal Wani, 2013).

Konsep pembelajaran ini mengubah bentuk pembelajaran konvensional menjadi pembelajaran bentuk digital (Subangkit Syafaat Ari dan Rudy Kustijono, 2013). Menurut Jaya Kumar C. Koran (dalam Mohammad Yazdi, 2012) e-learning merupakan pembelajaran menggunakan media elektronik seperti LAN, WAN, atau internet untuk menyampaikan isi pembelajaran, interaksi, dan bimbingan. Rosenberg (dalam Mohammad Yazdi, 2012) menjelaskan $e$ learning sebagai penggunaan teknologi internet untuk mengirimkan serangkaian solusi yang dapat meningkatkan pengetahuan dan keterampilan. Adapun bahan ajar dimuat dalam bentuk visual, audio, video, dan multimedia (Hilal Wani, 2013). E-learning juga cocok digunakan pada berbagai pendekatan atau model pembelajaran, baik pada pembelajaran tradisional maupun pembelajaran modern (Himanshu Agarwal \& Pandey, 2013). Sukardi (2007) menjelaskan terdapat tiga syarat kegitan belajar e-learning, 
yaitu (1) pemanfaatan jaringan internet, (2) tersedianya bahan ajar bersifat mandiri, dan (3) tersedianya dukungan layanan tutor yang dapat membantu peserta didik apabila mengalami kesulitan belajar.

Salah satu pendekatan pembelajaran yang tergantung dengan konsep e-learning adalah pendekatan pembelajaran flipped classroom. Bergman \& Sams (2012) menjelaskan Flipped classroom merupakan pendekatan pembelajaran yang menukar kegiatan-kegiatan di kelas, yaitu penyajian materi oleh guru menjadi kegiatan yang dilakukan di luar kelas. Arnold \& Garza (2014) menjelaskan bahwa flipped classroom merupakan pendekatan pembelajaran yang memberikan materi kepada peserta didik di rumah menggunakan media elektronik kemudian mengaplikasikan materi dalam aktivitas praktis di kelas. Manfaat dari flipped classroom adalah menciptakan pembelajaran yang aktif, kreatif, bertanggung jawab, kelas lebih efektif karena membebaskan banyak waktu, dan guru mempunyai kesempatan penuh untuk berinteraksi dengan masingmasing peserta didik saat pembelajaran di kelas (Nouri Jalal, 2016).

Barret D (dalam Yuni Evi Meliani, et al., 2017) mengemukankan manfaat Flipped classroom bagi peserta didik, yaitu peserta didik memiliki waktu untuk mempelajari materi sebelum pertemuan berlangsung, membantu kesulitan belajar, mengatasi stress akibat pekerjaan rumah, dan pembelajaran yang menarik menggunakan video dan website. Bishop \& Verlegar (2013) mengemukakan bahwa flipped classroom memiliki dua komponen penting: (1) penggunaan teknologi informasi dan komunikasi dan (2) keterlibatan kegiatan pembelajaran interaktif.

Salah satu teknologi informasi komunikasi yang banyak digunakan adalah web blog. Nanang Wahyudi (2014) mendefinisikan blog sebagai singkatan dari web blog yang artinya adalah suatu bentuk aplikasi layanan web yang dibuat untuk mempublikasikan informasi melalui tulisan dalam sebuah postingan. Sedangkan Nur Komariah (2016) mendefenisikan blog sebagai aplikasi web yang memuat tulisan dan gambar yang disebut postingan dalam sebuah halaman website. Kelebihan penggunaan blog yaitu dapat diakses kapan saja dan dimana saja, dapat diakses melalui komputer dan handphone, pembuatan blog dapat dilakukan dengan instan, mudah, gratis, dan dapat memuat bahan ajar berupa dokumen, audio, dan video. Hastungkara Singgih (2013) juga telah melakukan penelitian penggunaan blog dalam pembelajaran Hukum Newton dan menjelaskan terdapat peningkatan dalam hal minat, perhatian, semangat belajar, rasa senang, rasa puas, dan tanggung jawab siswa. Sesuai survei yang dilakukan kepada 30 peserta didik tentang ketertarikan pembelaja ran berbasis komputer dan smartphone menggunakan internet, didapatkan hasil bahwa peserta didik sangat tertarik belajar mengguna kan blog. Blog tidak menggantikan pendekatan belajar konvensional, namun dapat digunakan sebagai media pembelajaran untuk memper kuat pendekatan pembelajaran yang berbasis teknologi komputer dan komunikasi (Subangkit Syafaat Ari \& Rudy Kustijono, 2013). Dengan demikian blog sangat tepat sebagai media pembelajaran berbasis pendeka tan flipped classroom karena penggunaannya yang tidak terbatas waktu dan tempat. Pada blog dimuat berbagai kebutuhan peserta didik, seperti LKPD, video pembelajaran, kuis online, dan obrolan.

Berdasarkan ulasan yang telah diuraikan, maka kajian ini menarik dilakukan terkait tentang pengembangan blog pembelajaran fisika berbasis pendekatan flipped classroom untuk siswa kelas X MIPA Sekolah Menengah Atas.

\section{Bahan dan Metode}

Penelitian dilaksanakan di Laboratorium Pengembangan Media Pembelajaran Pendidikan Fisika FKIP Universitas Riau. Waktu penelitian dimulai dari bulan April sampai Oktober 2018. Metode penelitian yang digunakan adalah R\&D dengan tipe pengembangan ADDIE (analysis, design, development, implementation, and evaluation). Penelitian ini dilakukan hanya sampai pada tahap development. Tahap penelitian ini ditunjukkan seperti Gambar 1. 


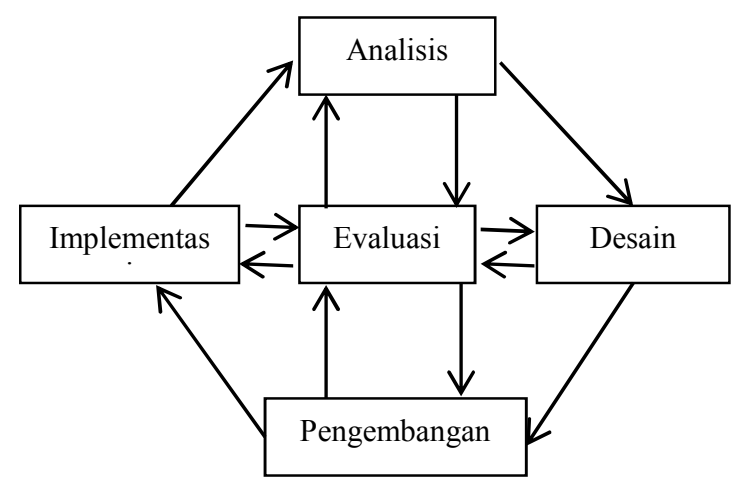

Gambar 1. Tahap-tahap model pengembangan ADDIE (Gusti Lanang Agung, et al., 2014).

Subjek penelitian adalah blog pembelajaran fisika berbasis pendekatan flipped classroom pada materi pokok usaha dan energi. Blog pembelajaran memuat LKPD, kuis online, video pembelajaran, dan obrolan. Instrumen penelitian terdiri dari lembar ketertarikan peserta didik terhadap pembelajaran menggunakan internet yang diisi oleh peserta didik dan lembar validitas blog pembelajaran yang diisi oleh enam orang validator yang terdiri dari tiga orang dosen pendidikan fisika sebagai pakar dan tiga orang guru bidang studi fisika sebagai pengguna.

Data hasil kuisioner peserta didik dianalisis secara deskriptif dengan mengguna kan teknik persentase dan pengkategorian tingkat validitas. Penentuan tingkat validitas blog pembelajaran berbasis pendekatan flipped classroom dilakukan dengan memberi skor penilaian pada setiap item indikator oleh pakar dan pengguna menggunakan skala Likert seperti pada Tabel 1.

Tabel 1. Kategori penilaian lembar validitas

\begin{tabular}{clc}
\hline No & \multicolumn{1}{c}{ Kategori } & Skor \\
\hline 1 & Sangat setuju & 4 \\
2 & Setuju & 3 \\
3 & Tidak setuju & 2 \\
4 & Sangat tidak setuju & 1 \\
\hline \multicolumn{2}{l}{ Sumber: (Djaali \& Muljono Pudji, 2008). }
\end{tabular}

Kemudian ditentukan skor rata-rata validitas dari pakar dan pengguna untuk masing-masing item indikator dan menentukan kategori nilai validitas sesuai dengan rentang skor seperti Tabel 2.
Tabel 2. Cara menentukan nilai validitas subjek penelitian.

\begin{tabular}{cll}
\hline $\begin{array}{c}\text { Skor Rata- } \\
\text { Rata }\end{array}$ & \multicolumn{1}{c}{ Kategori } & \multicolumn{1}{c}{$\begin{array}{c}\text { Nilai } \\
\text { Validitas }\end{array}$} \\
\hline $3,25<x \leq 4,00$ & Sangat tinggi & Sangat Valid \\
$2,50<x \leq 3,25$ & Tinggi & Valid \\
$1,75<x \leq 2,50$ & Rendah & Kurang Valid \\
$1,00<x \leq 1,75$ & Sangat Rendah & Tidak Valid \\
\hline
\end{tabular}

Sumber: (Umar Husein, 2011).

Kriteria penarikan kesimpulan pada penelitian ini adalah blog pembelajaran fisika berbasis pendekatan flipped classroom dinyatakan valid apabila memiliki skor ratarata berkategori tinggi atau sangat tinggi dengan nilai validitas valid atau sangat valid. Sebaliknya apabila skor rata-rata berada pada kategori rendah dan sangat rendah, maka dilakukan revisi sampai dinyatakan valid.

\section{Hasil dan Pembahasan}

Sebelum dilakukan pengembangan blog pembelajaran, maka dilakukan tahap analisis terhadap data yang diperoleh dari peserta didik tentang ketertarikan terhadap pembelajaran berbasis internet menggunakan komputer atau smartphone. Pengumpulan data dilakukan dengan pengisian kuisioner oleh 30 peserta didik yang tergabung dalam satu kelas dan sudah mempelajari materi usaha dan energi. Adapun data hasil analisisnya dapat dilihat pada Tabel 3 .

Berdasarkan Tabel 3, terlihat bahwa $100 \%$ peserta didik tertarik melakukan pembelajaran menggunakan internet (pernyataan 1), 93,33\% Peserta didik setuju bahwa dengan menggunakan internet memudahkan mereka memahami materi (pernyataan 2), 90\% peserta didik setuju bahwa internet memudahkan mereka mencari informasi belajar (pernyataan 3), $100 \%$ peserta didik mengenal blog sebagai salah satu media pembelajaran berbasis internet (pernyataan 4), 100\% peserta didik setuju bahwa pembelajaran usaha dan energi menggunakan blog menarik buat mereka (pernyataan 5), 100\% peserta didik setuju dengan adanya blog akan memudahkan mereka mengakses informasi belajar seperti video dan bahan ajar dengan cepat (pernyataan 6), 100\% peserta didik setuju bahwa pembelajaran menggunakan komputer dan smartphone menarik buat mereka 
(pernyataan 7), 100\% peserta didik setuju bahwa pembelajaran menggunakan komputer dan smartphone sesuai dengan perkembangan zaman mereka (pernyataan 8), dan $100 \%$ peserta didik setuju bahwa belajar menggunakan komputer dan smartphone sesuai dengan materi usaha dan energi karena bisa menonton video kapanpun dan dimanapun (pernyataan 9).

Berdasarkan tahap analisis tersebut, maka dilakukan desain blog pembelajaran berbasis pendekatan flipped classroom. Blog pembelajaran yang dikembangkan merupakan blog gratis yang disediakan oleh blogger, sehingga pembuatannya lebih ekonomis. Adapun desain blog pembelajaran yang dikembangkan dapat dilihat pada Gambar 2.

Setelah dilakukan tahap desain, maka dilakukan tahap pengembangan, yaitu tahap pembuatan blog pembelajaran. Adapun berbagai apikasi yang digunakan untuk mengembangkan blog dan berbagai konten didalamnya dapat dilihat pada Tabel 4. Aplikasi yang digunakan dalam membuat blog dan kontennya sangat mudah digunakan. Setelah dilakukan pembuatan blog, maka dihasilkan blog pembelajaran seperti Gambar 3.

Tabel 3. Data hasil ketertarikan peserta didik terhadap pembelajaran berbasis internet menggunakan teknologi komputer dan smartphone

\begin{tabular}{|c|c|c|c|c|c|}
\hline \multirow[t]{2}{*}{ No } & \multirow[t]{2}{*}{ Pernyataan } & \multicolumn{2}{|c|}{$\begin{array}{l}\text { Persetujuan } \\
(\%)\end{array}$} & \multicolumn{2}{|c|}{$\begin{array}{c}\text { Ketidaksetujuan } \\
(\%)\end{array}$} \\
\hline & & SS & $\mathrm{S}$ & KS & $\mathrm{TS}$ \\
\hline 1 & $\begin{array}{l}\text { Pembelajaran memanfaatkan internet sangat } \\
\text { menarik buat saya. }\end{array}$ & 43,33 & 56,67 & 0 & 0 \\
\hline 2 & $\begin{array}{l}\text { Saya merasa pembelajaran berbasis internet } \\
\text { memudahkan saya memahami materi karena } \\
\text { mudah untuk mengaksesnya. }\end{array}$ & 40,00 & 53,33 & 6,67 & 0 \\
\hline 3 & $\begin{array}{l}\text { Adanya pembelajaran } \\
\text { membuat saya mudah } \\
\text { informasi belajar. }\end{array}$ & 43,33 & 46,67 & 10,00 & 0 \\
\hline 4 & $\begin{array}{l}\text { Salah satu media pembelajaran berbasis } \\
\text { internet yang saya ketahui adalah blog. }\end{array}$ & 46,67 & 53,33 & 0 & 0 \\
\hline 5 & $\begin{array}{l}\text { Saya yakin pembelajaran usaha dan energi } \\
\text { menggunakan blog menarik buat saya. }\end{array}$ & 30,00 & 70,00 & 0 & 0 \\
\hline 6 & $\begin{array}{l}\text { Pada blog, saya dapat mengakses informasi } \\
\text { belajar, video, dan bahan ajar lebih cepat tanpa } \\
\text { harus menunggu pembelajaran di kelas. }\end{array}$ & 50,00 & 50,00 & 0 & 0 \\
\hline 7 & $\begin{array}{l}\text { Pemanfaatan teknologi seperti smartphone dan } \\
\text { komputer dalam pembelajaran menarik buat } \\
\text { saya. }\end{array}$ & 60,00 & 40,00 & 0 & 0 \\
\hline 8 & $\begin{array}{l}\text { Saya merasa belajar menggunakan smartphone } \\
\text { dan komputer sangat sesuai buat saya dan } \\
\text { kekinian. }\end{array}$ & 50,00 & 50,00 & 0 & 0 \\
\hline 9 & $\begin{array}{l}\text { Belajar menggunakan smartphone atau } \\
\text { komputer sesuai untuk materi usaha dan energi } \\
\text { karena bisa langsung menonton video } \\
\text { kapanpun dan dimanapun. }\end{array}$ & 40,00 & 60,00 & 0 & 0 \\
\hline
\end{tabular}

Keterangan: SS = Sangat Setuju, S = Setuju, KS = Kurang Setuju, TS = Tidak Setuju 


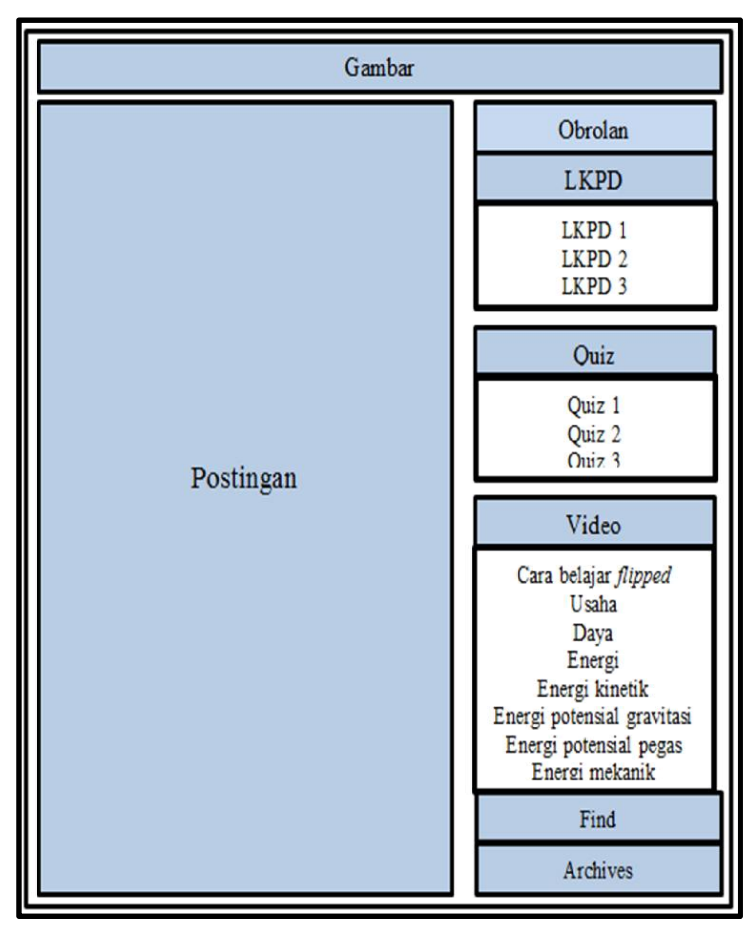

Gambar 2. Desain blog pembelajaran.

Berdasarkan Gambar 2 dapat dilihat beberapa menu yang dimuat dalam blog adalah menu obrolan, LKPD, kuis online, video yang terdiri dari 7 video pembelajaran dan 1 video cara belajar flipped classroom, archieve, dan find. Bagian atas blog memuat gambar yang sesuai dengan tema pendidikan dan postingan yang berupa halaman depan yang mencantum kan menu blog yang dipilih.

Tabel 4. Aplikasi yang digunakan dalam membuat produk pengembangan.

\begin{tabular}{cll}
\hline No & \multicolumn{1}{c}{ Produk } & \multicolumn{1}{c}{ Aplikasi } \\
\hline 1 & LKPD & Microsoft word 2010. \\
2 & Video Pem- & Sparkol video scribe, \\
& belajaran & movie maker, youtube. \\
3 & Blog & Blogger.com \\
4 & Kuis Online & Googleform \\
5 & Obrolan & Google group
\end{tabular}

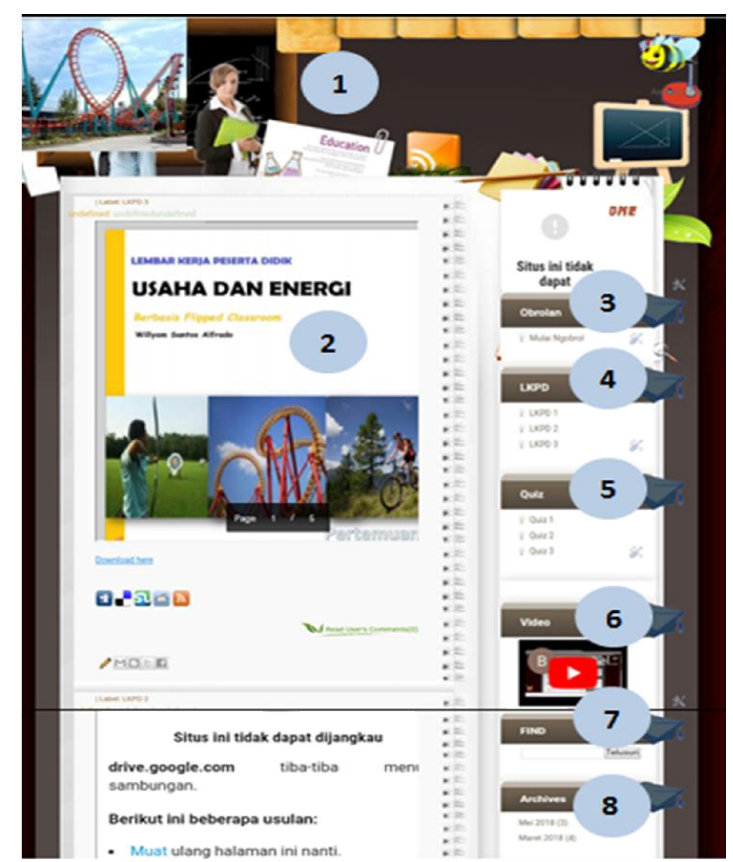

Gambar 3. Tampilan blog pembelajaran.

Tabel 5. Menu dan isi blog pembelajaran

\begin{tabular}{|c|c|c|}
\hline No & $\begin{array}{c}\text { Nama } \\
\text { Tampilan }\end{array}$ & Keterangan \\
\hline 1 & $\begin{array}{l}\text { Gambar } \\
\text { header }\end{array}$ & $\begin{array}{l}\text { Sesuai dengan templete } \\
\text { blog yang dikembangkan } \\
\text { oleh blogger. }\end{array}$ \\
\hline 2 & Postingan & $\begin{array}{l}\text { Layar utama yang memuat } \\
\text { bagian yang diklik pada } \\
\text { menu blog. }\end{array}$ \\
\hline 3 & Obrolan & $\begin{array}{l}\text { Digunakan sebagai } \\
\text { aplikasi chatting antara } \\
\text { sesama pengguna blog. }\end{array}$ \\
\hline 4 & LKPD & $\begin{array}{l}\text { Digunakan untuk } \\
\text { mengakses dan } \\
\text { mengunduh LKPD. } \\
\text { Terdiri dari } 3 \text { LKPD }\end{array}$ \\
\hline 5 & Kuis Online & $\begin{array}{l}\text { Digunakan untuk } \\
\text { mengerjakan kuis online. } \\
\text { Terdapat } 3 \text { kuis online. }\end{array}$ \\
\hline 6 & Video & $\begin{array}{l}\text { Digunakan untuk } \\
\text { menonton video } \\
\text { pembelajaran. Terdapat } 8 \\
\text { video pembelajaran. }\end{array}$ \\
\hline 7 & Find & $\begin{array}{l}\text { Digunakan untuk mencari } \\
\text { postingan pada blog sesuai } \\
\text { kata kunci. }\end{array}$ \\
\hline 8 & Archieve & $\begin{array}{l}\text { Digunakan untuk melihat } \\
\text { jumlah postingan blog. }\end{array}$ \\
\hline
\end{tabular}


Setelah blog pembelajaran selesai dibuat, maka dilakukan validasi oleh pakar yaitu 3 dosen pendidikan fisika dan pengguna yaitu 3 guru bidang studi fisika. Penilaian blog pembelajaran mencakup aspek isi, aspek tampilan, dan aspek kebahasaan. Adapun hasil validasi untuk aspek tampilan, aspek isi, dan aspek kebahasaan secara berturut-turut dapat dilihat pada Tabel 6, Tabel 7, dan Tabel 8.

Berdasarkan Tabel 6 terlihat bahwa skor rata-rata aspek tampilan blog pembelajaran yang diberikan pakar adalah 3,15 dengan kategori tinggi $(\mathrm{T})$ dan nilai validitas adalah valid, sedangkan pengguna memberi skor ratarata 3,69 dengan kategori sangat tinggi (ST) dan nilai validitas sangat valid. Wendy Rahmawan \& Suharyanto (2016) juga memperoleh kategori baik pada aspek tampilan blog pembelajaran fisika dan menjelaskan bahwa tampilan yang menarik dan interaktif menunjukkan tingkat intelegensi yang baik pula serta membangun motivasi penggunanya.

Berdasarkan Tabel 7 terlihat bahwa skor rata-rata aspek isi yang diberikan pakar adalah 3,19 dengan kategori tinggi (T) dan nilai validitas adalah valid, sedangkan pengguna memberi skor rata-rata 3,91 dengan kategori sangat tinggi (ST) dan nilai validitas sangat valid. Penilaian aspek isi mencakup penilaian LKPD, kuis online, dan video pembelajaran. Mengacu pada Tabel 2, aspek isi blog pembelajaran dinyatakan valid. Sejalan dengan penelitian Rahmawan \& Suharyanto (2016), aspek isi pada pengembangan blog mendapat kategori baik. Aspek isi menjadi sangat penting karena memuat kesesuaian dengan indikator dan tingkat kognisi peserta didik. Blog yang dikembangan berdasarkan pendekatan flipped classroom berisikan LKPD, kuis online, obrolan, dan video pembelajaran, sedangkan blog yang dikembangkan oleh Wendy Rahmawan \& Suharyanto (2016) berisikan materi, soal, dan simulasi.

Berdasarkan Tabel 8 terlihat bahwa skor rata-rata aspek kebahasaan blog pembelajaran yang diberikan pakar adalah 3,17 dengan kategori tinggi $(\mathrm{T})$ dan nilai validitas adalah valid, sedangkan pengguna memberi skor ratarata 3,58 dengan kategori sangat tinggi (ST) dan nilai validitas sangat valid. Wendy Rahmawan dan Suharyanto (2016) juga memperoleh skor dengan kategori baik untuk aspek kebahasaan pada pengembangan blog pembelajaran fisika. Hal yang sama juga diperoleh oleh Asep Dwi Purwoto (2017) tentang pengembangan WEB pembelajaran fisika dan menjelaskan bahwa aspek kebahasaan merupakan sangat penting karena disesuaikan dengan EYD daan tingkat kognitif peserta didik. Sebelum mendapat skor rata-rata dengan kategori tinggi dan sangat tinggi ini, sebelumnya telah dilakukan revisi sesuai saran validator seperti pada Tabel 9.

Tabel 6. Hasil analisis validitas aspek tampilan blog oleh pakar dan pengguna

\begin{tabular}{|c|c|c|c|c|c|c|c|}
\hline \multirow{3}{*}{ No } & \multirow{3}{*}{ Indikator } & \multicolumn{6}{|c|}{ Skor Validasi } \\
\hline & & \multicolumn{3}{|c|}{ Pakar } & \multicolumn{3}{|c|}{ Pengguna } \\
\hline & & Rerata & Kategori & Validitas & Rerata & Kategori & Validitas \\
\hline 1 & $\begin{array}{l}\text { Tampilan blog menarik dan } \\
\text { mudah dipahami. }\end{array}$ & 3,33 & ST & SV & 4,00 & ST & SV \\
\hline 2 & $\begin{array}{l}\text { Tulisan pada blog sangat jelas } \\
\text { dan tidak terdapat kesalahan } \\
\text { pengetikan. }\end{array}$ & 3,00 & $\mathrm{~T}$ & $\mathrm{~V}$ & 3,33 & ST & SV \\
\hline 3 & $\begin{array}{l}\text { Ukuran tulisan yang } \\
\text { digunakan sangat tepat. }\end{array}$ & 3,00 & $\mathrm{~T}$ & V & 4,00 & ST & SV \\
\hline 4 & $\begin{array}{l}\text { Kualitas visual (foto, gambar, } \\
\text { dan grafis) baik. }\end{array}$ & 3,33 & ST & SV & 3,33 & ST & SV \\
\hline 5 & $\begin{array}{l}\text { Ukuran gambar sesuai } \\
\text { (proporsional) }\end{array}$ & 3,00 & $\mathrm{~T}$ & V & 3,33 & ST & SV \\
\hline 6 & $\begin{array}{l}\text { Tampilan blog menarik dan } \\
\text { memotivasi. }\end{array}$ & 3,00 & $\mathrm{~T}$ & V & 4,00 & ST & SV \\
\hline 7 & Efisiensi dalam penggunaan. & 3,00 & $\mathrm{~T}$ & $\mathrm{~V}$ & 3,67 & ST & SV \\
\hline 8 & Blog dilengkapi dengan video & 3,00 & $\mathrm{~T}$ & V & 3,67 & ST & SV \\
\hline
\end{tabular}




\begin{tabular}{|c|c|c|c|c|c|c|c|}
\hline \multirow{3}{*}{ No } & \multirow{3}{*}{ Indikator } & \multicolumn{6}{|c|}{ Skor Validasi } \\
\hline & & \multicolumn{3}{|c|}{ Pakar } & \multicolumn{3}{|c|}{ Pengguna } \\
\hline & & Rerata & Kategori & Validitas & Rerata & Kategori & Validitas \\
\hline & $\begin{array}{l}\text { pembelajaran, LKPD, kuis } \\
\text { online sesuai pendekatan } \\
\text { flipped classroom. }\end{array}$ & & & & & & \\
\hline 9 & $\begin{array}{l}\text { LKPD menarik dan } \\
\text { memotivasi. }\end{array}$ & 3,33 & ST & SV & 3,67 & ST & SV \\
\hline 10 & Konsistensi penyajian LKPD. & 3,33 & ST & SV & 3,67 & ST & SV \\
\hline 11 & Kualitas gambar video baik. & 3,33 & ST & SV & 3,67 & ST & SV \\
\hline 12 & Kualitas suara yang baik & 3,00 & $\mathrm{~T}$ & V & 3,67 & ST & SV \\
\hline 13 & Perpaduan gambar yang sesuai & 3,00 & $\mathrm{~T}$ & $\mathrm{~V}$ & 3,33 & ST & SV \\
\hline 14 & $\begin{array}{l}\text { Animasi yang representatif } \\
\text { dan menarik }\end{array}$ & 3,33 & ST & SV & 4,00 & ST & SV \\
\hline 15 & $\begin{array}{l}\text { Durasi waktu video sesuai } \\
\text { kebutuhan }\end{array}$ & 3,33 & ST & SV & 4,00 & ST & SV \\
\hline & Rata-Rata & 3,15 & $\mathrm{~T}$ & $\mathrm{~V}$ & 3,69 & ST & SV \\
\hline
\end{tabular}

Keterangan : ST $=$ Sangat Tinggi, $\mathrm{T}=$ Tinggi, $\mathrm{SV}=$ Sangat Valid, $\mathrm{V}=$ Valid

Aspek tampilan diadaptasi dari (Novia Ainul Izza, 2012; Sulastri, 2015; Kurnia Sari, et al.,2017).

Tabel 7. Hasil analisis validitas aspek isi blog oleh pakar dan pengguna

\begin{tabular}{|c|c|c|c|c|c|c|c|}
\hline \multirow{3}{*}{ No } & \multirow{3}{*}{ Indikator } & \multicolumn{6}{|c|}{ Skor Validasi } \\
\hline & & \multicolumn{3}{|c|}{ Pakar } & \multicolumn{3}{|c|}{ Pengguna } \\
\hline & & Rerata & Kategori & Validitas & Rerata & Kategori & Validitas \\
\hline 1 & $\begin{array}{l}\text { Kesesuaian soal LKPD } \\
\text { dengan kompetensi } \\
\text { dasar. }\end{array}$ & 3,00 & $\mathrm{~T}$ & $\mathrm{~V}$ & 4,00 & ST & SV \\
\hline 2 & $\begin{array}{l}\text { Kesesuaian soal LKPD } \\
\text { dengan indikator } \\
\text { pencapaian kompetensi }\end{array}$ & 3,00 & $\mathrm{~T}$ & V & 4,00 & ST & SV \\
\hline 3 & $\begin{array}{l}\text { Kesesuaian LKPD } \\
\text { dengan fakta kehidupan } \\
\text { sehari-hari }\end{array}$ & 3,67 & ST & SV & 3,67 & ST & SV \\
\hline 4 & $\begin{array}{l}\text { Kesesuaianisi video } \\
\text { dengan kompetensi } \\
\text { dasar. }\end{array}$ & 3,33 & ST & SV & 4,00 & ST & SV \\
\hline 5 & $\begin{array}{l}\text { Kesesuaian isi video } \\
\text { dengan indikator } \\
\text { pencapaian kompetensi }\end{array}$ & 3,00 & $\mathrm{~T}$ & V & 4,00 & ST & SV \\
\hline 6 & $\begin{array}{l}\text { Soal kuis pada blog } \\
\text { sesuai dengan } \\
\text { kompetensi dasar }\end{array}$ & 3,00 & $\mathrm{~T}$ & V & 3,67 & ST & SV \\
\hline 7 & $\begin{array}{l}\text { Soal kuis pada blog } \\
\text { sesuai dengan indikator } \\
\text { pencapaian } \\
\text { kompetensi. }\end{array}$ & 3,33 & ST & SV & 4,00 & ST & SV \\
\hline & Rata-Rata & 3,19 & $\mathrm{~T}$ & V & 3,91 & ST & SV \\
\hline
\end{tabular}

Keterangan : ST $=$ Sangat Tinggi, $\mathrm{T}=$ Tinggi, $\mathrm{SV}=$ Sangat Valid, V = Valid

Aspek isi diadaptasi dari (Novia Ainul Izza, 2012; Sulastri, 2015; Kurnia Sari, et. a., 2017). 
Tabel 8. Hasil analisis validitas aspek kebahasaan blog oleh pakar dan pengguna

\begin{tabular}{|c|c|c|c|c|c|c|c|}
\hline \multirow{3}{*}{ No } & \multirow{3}{*}{ Indikator } & \multicolumn{6}{|c|}{ Skor Validasi } \\
\hline & & \multicolumn{3}{|c|}{ Pakar } & \multicolumn{3}{|c|}{ Pengguna } \\
\hline & & Rerata & Kategori & Validitas & Rerata & Kategori & Validitas \\
\hline 1 & $\begin{array}{l}\text { Bahasa yang digunakan } \\
\text { pada LKPD sesuai dengan } \\
\text { tingkat berfikir siswa }\end{array}$ & 3,00 & $\mathrm{~T}$ & $\mathrm{~V}$ & 3,33 & ST & SV \\
\hline 2 & $\begin{array}{l}\text { Bahasa yang digunakan } \\
\text { dalam LKPD sesuai EYD. }\end{array}$ & 3,00 & $\mathrm{~T}$ & $\mathrm{~V}$ & 4,00 & ST & SV \\
\hline 3 & $\begin{array}{l}\text { Bahasa yang digunakan } \\
\text { pada video sesuai dengan } \\
\text { tingkat berfikir siswa. }\end{array}$ & 3,00 & $\mathrm{~T}$ & $\mathrm{~V}$ & 3,33 & ST & SV \\
\hline 4 & $\begin{array}{l}\text { Bahasa yang digunakan } \\
\text { dalam video sesuai EYD. }\end{array}$ & 3,67 & ST & SV & 3,67 & ST & SV \\
\hline & Rata-Rata & 3,17 & $\mathrm{~T}$ & $\mathrm{~V}$ & 3,58 & ST & SV \\
\hline
\end{tabular}

Keterangan : ST $=$ Sangat Tinggi, $\mathrm{T}=$ Tinggi, $\mathrm{SV}=$ Sangat Valid, $\mathrm{V}=$ Valid

Aspek kebahasaan diadaptasi dari (Novia Ainul Izza, 2012; Sulastri, 2015; Kurnia Sari, et. a., 2017).

Tabel 9. Saran-saran perbaikan oleh validator pada blog pembelajaran

\begin{tabular}{cll}
\hline No & \multicolumn{1}{c}{ Komentar dan Saran } & \multicolumn{1}{c}{ Keterangan } \\
\hline 1 & $\begin{array}{l}\text { Sesuaikan soal kuis pada blog dengan } \\
\text { kompetensi dasar }\end{array}$ & $\begin{array}{l}\text { Sudah disesuaikan dengan kompetensi } \\
\text { dasar. }\end{array}$ \\
2 & $\begin{array}{l}\text { Sesuaikan soal kuis pada blog dengan } \\
\text { indikator pencapaian kompetensi }\end{array}$ & $\begin{array}{l}\text { Sudah disesuaikan dengan indikator } \\
\text { pencapaian kompetensi. }\end{array}$ \\
3 & $\begin{array}{l}\text { Sesuaikan durasi waktu video dengan } \\
\text { kebutuhan }\end{array}$ & $\begin{array}{l}\text { Sudah disesuaikan dengan waktu lebih } \\
\text { kurang 15 menit. }\end{array}$ \\
\hline
\end{tabular}

\section{Kesimpulan dan Saran}

Berdasarkan hasil dan pembahasan dari penelitian ini, maka dapat disimpulkan bahwa telah dihasilkan blog pembelajaran fisika berbasis pendekatan flipped classroom dengan aspek isi, aspek kebahasaan, dan aspek tampilan yang valid dan layak digunakan.

Terkait penelitian ini, penulis menggunakan metode penelitian R\&D dengan tipe pengembangan ADDIE yang terdiri dari tahap analysis, design, development, implementation, and evaluation. Namun pada pelaksanaannya, peneliti hanya sampai pada tahap pengembangan (development). Maka dari itu penulis merekomendasikan untuk melakukan tahap implementasi, yaitu uji empiris atau praktikalitas dan melihat pengaruh blog terhadap hasil belajar dan motivasi belajar peserta didik. Blog juga dapat dikembangkan lagi dengan memuat simulasi konsep usaha dan energi serta meningkatkan kualitas video pembelajaran.

\section{Daftar Pustaka}

Arief Sadiman, 2012. Media Pendidikan Pengertian Pengembangan Dan Pemanfaatannya. PT Raja Grafindo Persada, Jakarta.

Arnold, S.G \& Garza, 2014. The Flipped Classroom Teaching Model and Its Use for Information Literacy Instruction. Journal Communication in Information Literacy, 8 (1), 7-22.

Arsyad, 2013. Media Pembelajaran. PT Grasindo Persada, Jakarta.

Asep Dwi Purwoto, 2017. Pengembangan WEB Pembelajaran Fisika sebagai 
Media Pembelajaran Mata Kuliah Fisika Kuantum. Skripsi. Universitas Islam Negeri Raden Intan. Lampung.

Bambang Warsita, 2008. Teknologi Pembelajaran Landasan dan Aplikasinya. Rineka Cipta, Jakarta.

Bergmann \& Sams, 2012. Flip Your Classroom. ISTE ASCD, Washington DC.

Bishop, J. L., \& Verlegar, M. A., 2013. The Flipped Classroom. Survey of The Research $120^{\text {th }}$ ASEE Annual Conference and Expotition. American Society for Enginering Education. Atlanta.

Darmansyah, 2010. Pembelajaran Berbasis $W E B$, UNP Press, Padang.

Djaali \& Muljono Pudji, 2008. Pengukuran dalam Bidang Pendidikan. Program Pasca Sarjana UNJ, Jakarta.

Gusti Lanang Agung Kartika Putra, Dewa K. Tastra, \& IGN I Wy Suwatra, 2014. Pengembangan Media Video Pembelajaran dengan Pendekatan ADDIE Pada Pembelajaran Bahasa Inggris di SDN 1 Selat. Jurnal Edutech Universitas Pendidikan Ganesha Jurusan Teknologi Pendidikan, 2 (1), 1-10.

Hastungkara Singgih, 2013. Pengembangan Media Pembelajaran Fisika Berbantuan Blog pada Pokok Bahasan Hukum Newton Tentang Gerak untuk Meningkatkan Motivasi Belajar Siswa Kelas X SMA. Jurnal Pendidikan Fisika S1, 2 (3), 1-6.

Hilal Wani, 2013. The Relevance of Learning in Higher Education. Jurnal Kajian Pendidikan, 3(2), 180-194.

Himanshu Agarwal \& Pandey, G. N., 2013. Impact of E-Learning in Education. International Journal of Science and Research (IJSR), 2 (12), 146-148.

Husein Umar, 2011. Metode Penelitian Untuk Skripsi Dan Tesis Bisnis Edisi 11. PT. Bumi Aksara, Jakarta.

Kurnia Sari, Wiyatmo, \& Yusman, 2017. Pengembangan Perangkat Pembelajaran Hukum Newton Berbasis Problem Based Learning (PBL) untuk Meningkat kan Kemampuan Pemecahan Masalah dan Sikap Kerjasama Peserta Didik Kelas X SMA N 2 Baguntapan. Skripsi.
Universitas Negeri Yogyakarta, Yogyakarta.

Mohammad Yazdi, 2012. E-Learning Sebagai Media Pembelajaran Interaktif Berbasis Teknologi Informasi. Jurnal Ilmiah Foristek, 2 (1), 143-152.

Nanang Wahyudi, 2014. Pemanfaatan Blog Sebagai Media Pembelajaran Interaktif. Jurnal Studi Islam Panca Wahana, 12(10), 84-94.

Nouri Jalal, 2016. The Flipped Classroom for Active, Effective and Increased Learning Especially for Low Achievers. Journal International of Education Technology in Higher Education, 13(33), 1-10.

Novia Ainul Izza, 2012. Pengambangan Blog Sebagai Sumber Belajar Geografi Pokok Bahasan Biosfer Untuk Siswa SMA Kelas X1 IPS. Ejournal Universitas Negeri Yogyakarta 1(2):1-10.

Subangkit Syafaat Ari dan Rudy Kustijono, 2013. Pengembangan Blog sebagai Media Pembelajaran Fisika Pada Materi Gerak. Jurnal Inovasi Pendidikan Fisika, 2(3), 221-224.

Sukardi, 2007. Pengembangan e-Learning UNY. Laporan Penelitian Institusional. Universitas Negeri Yogyakarta, Yogyakarta.

Sulastri, 2016. Pengembangan Media Pembelajaran Arabic Thematic Video Pada Keterampilan Berbicara Bagi Siswa Kelas VIII MTS. Journal of Arabic Learning and Teaching 5(1):21-27.

Sumit Goyal, 2013. E-learning Future of Education. Journal of Education and Learning, 6(2), 239-242.

Wendy Rahmawan dan Suharyanto, 2016. Pengembangan Media Physics Academic Blog Pada Materi Impuls Dan Momentum Sebagai Alternatif Sumber Belajar Mandiri Peserta Didik SMA/MA Kelas XI Semester. Jurnal Pendidikan Fisika, 5(7), 446-453.

Yuni Evi Meliani, Wayan Suana, \& Agus Suyatna, 2017. Pengembangan Perangkat Pembelajaran Flipped Classroom Pada Materi Impuls Dan Momentum. Jurnal Edumatsains, 2(1), 55-71. 